\title{
Innovation activity in the hotel industry
}

\author{
Ester Martínez-Ros ${ }^{\mathrm{a}, 1}$, Francina Orfila-Sintes ${ }^{\mathrm{b}, *} \equiv$ \\ a Department of Business Administration, Carlos III University, C/Madrid, 126. 28903 Getafe, Madrid, Spain \\ ${ }^{\mathrm{b}}$ Department of Business Administration, University of the Balearic Islands, Cra. Valldemossa, Km. 7,5. 07122 Palma de Mallorca, Balearic Islands, Spain
}

Keywords:

Radical innovation

Incremental innovation

Hotel services

Balearic islands

\begin{abstract}
A B S T R A C T
This paper provides evidence for different innovation activities in the hotel industry. In particular, we explore the influence of a variety of firm and market characteristics on radical and incremental innovations. We consider the learning of new attributes (radical) and the addition of characteristics to existing attributes (incremental) to represent two different paces or degrees of managing the innovation process in this specific industry. The database used in the empirical study shares the major features of new approaches about innovation in services. A questionnaire administered to a representative sample of hotel managers in the Balearic Islands provides the data for the discrete regression models used to represent the innovation in these hotels. Our main conclusion is that radical and incremental innovations appear to be interrelated. Furthermore, the main determinants of innovation are the form of hotel management, the hotel market strategy, and the size and location of the hotel.
\end{abstract}

\section{Introduction}

This paper explores the main determinants of innovation conducted by firms in the lodging sector or, more specifically, the hotel sector and, following Gallouj and Weinstein (1997), distinguishes two degrees of innovation: radical and incremental. A review of the literature provides suggestions on the determining factors for each type of innovation and the degree to which the factors differ (Gatignon et al., 2002). Our proposal is to define innovation activity as two innovation degrees in which client intensity is monitored by hotels and leads to the introduction of additional characteristics to existing attributes (incremental innovation) or to the adoption of a new attribute (radical innovation) in the services provided, although these changes in the service may come from process innovation. We focus on the idea that innovation activity may be differentiated as a function of the pace at which it was introduced in the hotel, giving information on the degree of radicalness (Amis and Slack, 2004).

It has been noted in recent literature that the treatment of service innovation is challenging (Drejer, 2004; Coombs and Miles, 2000). We contend that innovation in services engages elements of innovation processes that are relevant for secondary and tertiary sectors. Following the contribution of Gallouj and Weinstein (1997) and Drejer (2004) to the service innovation literature, we use an autonomous survey to develop an integrative

\footnotetext{
* Corresponding author. Tel.: +34971171331; fax: +34971172389.

E-mail addresses: emros@emp.uc3m.es (E. Martínez-Ros), francina.orfila@uib.es (F. Orfila-Sintes).

${ }^{1}$ Tel.: +31916249350; fax: +34916249607.
}

approach in which innovations are represented in a model of firm and market characteristics that determines different degrees to which innovations are managed, depending on the attributes being learned (a new attribute to the hotel) or added (an addition to an existing hotel attribute). Our purpose departs from the traditional analysis of technological innovation in manufacturing activities because we claim that it is possible to deal with a supra framework of innovation processes whereby, independent of the typology of a service, we may refer to innovation activity. In that sense, we embrace the Schumpeterian perspective of innovation in which economic development is driven by the discontinuous emergence of new combinations (innovations) that are economic ally more viable than the old way of doing things (Schumpeter, 1934).

According to Metcalfe and Miles (2000), we recognise the importance of service innovations in two ways: (1) service firms can be innovative in their own right and (2) service firms play an important role in the evolving division of creative labour, which is characteristic of modern innovation systems. We chose to study the tourism industry because it plays a major role in the world economy (Balaguer and Cantavella Jordá, 2002) and because, in today's globally competitive tourism sector, destinations cannot remain competitive without the implementation of proper business innovations (Huybers and Bennett, 2000). By gaining a better understanding of the innovative activity of tourism firms, we can develop insights into actions that would improve their competitiveness and create a set of positive externalities for the rest of the economy by contributing to the competitiveness of the tourism destination.

Because innovation differs between the service and manufac turing sectors (Damanpour, 1996) and within the service sector 
(Amable and Palombarini, 1998), it is important to study specific types of services. Roberts et al. (2000), provide an interesting definition of the tertiary sector that includes transformations in the state of the environment, the state of the artefacts produced by the secondary sector, the state of people, and the state of information. Using this classification, our study can be framed within the transformations in the state of people, at least in the sense of offering them good leisure and a pleasant break. Hence, this study is centred on the lodging sector, one we chose because of its relative economic weight and its homogeneity. Innovation also presents differences among firms (Landau, 1991), and these differences are observed by considering innovation as a function of the internal resources of the company and the company's specific behaviours in the market. Hotels are classified into the category of a high level of client intensity (Coombs and Miles, 2000) because there is a great reliance on interactions between clients and service suppliers exchanges that provide important information for the hotel's information and technology systems. Our analyses provide useful information for hotel owners and managers and should assist them in developing policies that promote innovation in the tourism sector.

The empirical evidence we collected on a representative sample of hotel accommodation facilities from the Balearic Islands allows us to analyse the variables that influence the distinct degrees of innovation carried out by hotels.

This paper is structured as follows: Section 2 introduces a theoretical framework of innovation and its degree of radicalness; Section 3 develops the hypothesis regarding the degree of innovation of hotels; Section 4 presents the empirical methodology; Section 5 provides the results of this study; and Section 6 offers a discussion of results and presents our conclusions.

\section{Theoretical framework}

\subsection{The innovation phenomenon and degrees}

According to Schumpeter, innovation is the creation of new possibilities for additional valued added, taking into account not only the typical product/process innovation of manufacturing but also market, organisational, and resource input innovation. As competition intensifies and the pace of change accelerates, firms need to exploit existing competences or exploring new opportu nities (Jansen et al., 2006; Floyd and Lane, 2000). The concept of exploration and exploitation in innovation emerged from Dan neels (2002), Lee et al. (2003) and Rothaermel and Deeds (2004) to investigate the capacity of firms to develop both types of innovation converting them in an ambidextrous organisations (Gibson and Birkinshaw, 2004; He and Wong, 2004). There is little evidence of the study of exploratory and exploitative develop ment. The majority of empirical analyses concentrate on the relation between radical and incremental innovation with mixed results (Cardinal, 2001; Damanpour, 1991; Ettlie et al. 1984; Dewar and Dutton, 1986).

Traditionally, the degree of radicalness has been determined by applying the criteria derived from a review of the relevant literature on this issue. The criterion set for radicalness by Ettlie et al. (1984) is the magnitude of the cost of the change. They note that those innovations that incorporate a technology that represents a clear break from an existing practice (a new technology that requires changes in both procedures and products) will probably entail a significant cost that defines the innovation as radical rather than as incremental. Dewar and Dutton (1986) distinguish innovations according to the degree to which they incorporate new knowledge in relation to their risk.
They identify radical innovations as fundamental and revolu tionary changes in the technology, involving new knowledge that breaks with existing practice and is positively related to the risk involved in attempting the innovation. Incremental changes are improvements in or adaptations of current technology that are less costly and have more predictable results. Likewise, they note that the requirements in knowledge resources will depend on the perception of those familiar with the innovation's degree of departure from the knowledge state prior to its introduction. In a study of the effects of organisational complexity on innovation, Damanpour (1996) defines radical innovations as those that cause fundamental changes in the structure, procedures, and activities of the organisation; and that represent a large, clear break with existing practices. Incremental innovations, in contrast, cause a lesser break with the existing practices.

Up to this point, all definitions refer to the standard typology of innovation. We depart from them in the sense that we adapt an innovation definition for service according to Gallouj and Weinstein (1997). Yet, Sundbo (1997) identified innovation in the service sectors and distinguished it from learning, in that innovation is an act that is strategically reproduced and a factor that is associated with a greater jump in turnover or profit. He classified these innovations as being radical or incremental. Following Sundbo (1997), we measure radical innovation style as a clear break with existing practices or technologies and ones that are more likely than are incremental innovations to incorporate new knowledge. Radical innovations also tend to be riskier and more costly and would cause greater changes in the structure, procedures, products, or activities of the organisation. Radical innovations, understood to be applications of solutions for problems that are unsolved up to a given time, usually involve an elevated cost and have a great potential for impact on company profits. They are linked with the cumulative learning process. In contrast to a radical innovation, an incremental innovation usually involves less cost and less impact on company profit, regardless of the importance of the continual incremental innovation to the firm's competitiveness. Thus, incremental innovation represents the addition of services attributes to an existing service in the same sense that exploitation and exploration innovation in Danneels (2002), Lee et al. (2003), and Rothaermel and Deeds (2004).

Therefore, in our context, we differentiate between radical and incremental innovation, using a dimension that denotes whether they were introduced for the first time (learned or explored) or consisted of modifications, improvements, or extensions to previously introduced innovations (additional or exploitative). In our scheme, the first time a firm includes or adopts an innovation, is a radical innovation; whereas modification to a previous innovation represents an incremental innovation.

The conceptualisation of innovation in service, following Gallouj and Weinstein (1997), is any change in one or more terms from one or more vectors of characteristics that form the system that represents any service. Added to the characteristics typical of the system representing a manufactured good (i.e. the character istics of end use or product performance, and the techniques of production) are those derived from the greater interaction between lender and consumer that typifies the service sector (i.e. the competencies mobilised by the lender and those contributed by the consumer).

Innovation in one sector or area of economic activity tends to be heterogeneous, suggesting that it is best approached by classifying it according to its characteristics or attributes (Ga tignon et al., 2002). Although there are many service firms that introduce definite products (ones that tend to be adopted or not adopted at one point in time, for example, a new electronic pass keys to replace metal keys for entering hotel room doors), we 
believe that hotels are more likely to engage in a continuous change mode of innovation. As for the provision process in manufacturing firms, hotel service firms strive for increased service efficiency that will result in improved service output. Often hotels achieve competitive advantage by improving the efficiency of their service provision processes, and their compe titive advantage relies on changing the level or degree of service attributes offered and the extent of internal resources devoted to various dimensions of service operations (Ottenbacher and Gnoth, 2005). In this sense, it will be convenient to distinguish between two degrees of innovation radical and incremental while adapting our innovation definition to the service offered to client. Radicalness captures the extent to which degrees of innovation differ with respect to several determining factors, namely, levels of attainment, investment efforts, and the type of organisation monitoring.

\subsection{The hotel industry}

Innovation presents an intersectorial diversity (Amable and Palombarini, 1998; Pavitt, 1984) that will emerge from among the different activities in the tourism sector. Services in general are highly heterogeneous and include a great variety of interesting, complex, and often highly innovative activities; this implies that it is not possible to provide a general account of services innovation (Miles, 2000). Because there is a diversity of services in the tourism sector (Tremblay, 1998), we need to concentrate on one of them. We have chosen the lodging sector one that includes a set of companies that is homogenous in production and in compe titive setting. Moreover, this sector is important because it is indispensable for the development of the remaining services required of a tourism destination and because it represents a high relative weight in the totality of tourist expenditure.

Arrivals and income in the Spanish lodging sector have increased year after year in the late twentieth and early twenty first century. By accommodation type, $71 \%$ of tourists stayed at hotels; whereas the remainder stayed in rented properties and other less usual types of lodging facilities. As for the main national destinations, visitors to Spain prefer the archipelagos. The Balearic Islands and the Canary Islands are the top destinations, account ing for $43 \%$ of tourist arrivals to Spain.

The lodging sector in these Spanish archipelagos is mainly in the hands of private investors. In comparing the innovation activity of tourism with the figures of any manufacturing sector, the relative magnitude of service innovation efforts is small. In particular, for the Balearic Islands, annual R\&D expenditure as a percentage of GDP averaged only $0.36 \%$.

Because the innovation activity depends on the sector, we devote our analysis to delving into how the managers make decisions about the timing of introducing innovation in the hotel industry. Innovation in one sector or area of economic activity tends to be heterogeneous, suggesting that its study is best approached by classifying it according to its characteristics or attributes (Gatignon et al., 2002). As previously mentioned, although there are many service firms that introduce definite products, we believe that hotels are more likely to engage in a continuous change mode of innovation with a really low internal $\mathrm{R}+\mathrm{D}$ activities as Hjalager (2002) shows. The ability to deliver competitively superior hotel services is often a function of innovations made to the provision process (Hjalager, 1998). In this sense, it is convenient to distinguish two degrees of innovation radical and incremental but adapting our innova tion definition to the service offered to clients. That is, we use an ad hoc innovation approach. Nevertheless, with this ad hoc innovation approach, we capture an important part of the radicalness degree since we consider that the first time an innovation is introduced, it means a new knowledge with a clear break from an existing practice and a change in the structure, procedures or/and activities. Consequently, these considered radical innovations will be riskier and more costly than incre mental innovations considered as modifications, improvements, or extensions to previously introduced innovations. For example, the first time a hotel implements environmental measures is adding new service attributes since it is incorporating new knowledge with clear break down from an existing practice. Further, improvements in the environmental quality management will be lesser riskier because of the previous incorporated knowledge.

\section{Hypotheses}

\subsection{Innovation degree}

Service is an important factor in the provision of tourist lodgings; and as for other service sectors, the introduction of technological assets is important in achieving service efficiency and improvements in service output. Therefore, innovation consists of the adoption of technological improvements in the areas, departments, and services that are key elements in provision of services (Hjalager, 2002): control processes such as quality control and control of environmental management, computer equipment, information and telecommunications tech nologies, kitchens, food and beverage service, rooms, and main tenance and savings in utilities, security, and cleaning and laundry service. In these areas, the incorporation of technologies devel oped internally or sourced from commercial suppliers is apt to be translated into a competitive advantage, either because of productive efficiency (decreased costs) or because of increased service differentiation (improving the service provided by adapt ing it to consumer demand). Simultaneously, the innovations in these areas may be categorised as radical or incremental, according to whether they were introduced for the first time or consisted of modifications, improvements, or extensions to previously introduced innovations. The first time inclusion or adoption of innovations that are internally developed or sourced from commercial suppliers incorporates all the dimensions relevant to radicalness; whereas such incremental innovations as improvements incorporate a lesser degree of radicalness.

In the study of inter firm differences in decisions relating to innovations that vary in degree of radicalness, it is assumed that the differences depend on the firm's internal resources and its competitive position in the market (Sundbo, 1997) that the firm's distinct innovation will depend on its specific resources and capabilities. Nevertheless, assuming that the internal resources and capacities are valuable to the extent to which they allow firms to operate competitively in specific markets, the firm's market behaviour should also be included in the explanation. Therefore, for radical and incremental innovation degrees, the internal characteristics of the companies and the characteristics of their market competition are examined. We also consider the possibi lity that the two degrees of innovation may be interdependent.

Because radical innovation degree entails a learning process (Gallouj and Weinstein, 1997), it can be deduced that incremental innovation necessarily occurs after a radical innovation. Never theless, this sequential dependency does not exclude simultane ity, to the extent that all the resources and capacities developed for either of the two degrees will be of great value for the other degree (Damanpour, 1996). The resources and capacities that are valuable in radical innovation, which are of higher cost and greater complexity, will also be valuable in incremental 
innovation. Similarly, the updating of resources and capacities associated with incremental innovation will allow for a more rapid accumulation and generation of more complex knowledge, resources, and capacities that are required for radical innovation (Sirilli and Evangelista, 1998). Therefore, although the simultane ity of the two types of innovation could be restrained because of the limited resources available, we formulate the following hypotheses:

Hypothesis 1a. The hotel establishments that have introduced incremental innovation have a greater probability of innovating radically.

Hypothesis 1b. The hotel establishments that have introduced radical innovation have a greater probability of innovating incrementally.

\subsection{Ownership and management}

The corporate governance of a firm could be a determinant of the degree of innovation developed inside the organisation. Moreover, the organisational structure of the productive unit provides the framework in which decisions are made. Therefore, the form of management of the productive unit is an organisa tional resource that may influence both of innovation degrees (Sirilli and Evangelista, 1998). The hotel may be managed by its owners or by another entity that acts as a contract manager for the owners (e.g. a rental contract or a management contract), involving different incentives and risks (Getz and Carlsen, 2005). Some authors have suggested that the owner manager form of structure could mean lesser resources, less specialisation in management, and less professional managers (Getz and Carlsen, 2005), all of which can negatively influence the innovative activity because of a poor understanding of the determinants of competi tiveness. However, it can be argued that the owner manager structure can be a positive factor in innovation, considering the risks that are associated with the alternate form, a rental or management contract. For example, in order to acquire specialised management, owners must mediate a contract for the exploitation of the business and incur increased risks such as potential losses in the case of breach of contract or the greater costs associated with renegotiating the contract. It is expected, therefore, that at the time of mediating a management contract, decisions are made in favour of adopting innovations that are less risky innovations for which short term economic profitability is highly probable, or innovations that are required in order to stay in the market. In fact, it has been argued that the attitude of managers confronting the innovation change may determine the degree of radicalness of the innovations adopted (Damanpour, 1996; Dewar and Dutton, 1986; Ettlie et al., 1984). In particular, management factors have been found to be more important influences on innovation in the service sector than in the manufacturing sector (Preissl, 2000). In the hotel industry, Guerrier and Deery (1998) point out that the unit management constitutes strategic skills for management of service quality and for handling risk and uncertainty. As well, these authors highlighted management attitudes as being im portant determinants of the development or acquisition of innovation by tourism business. Getz and Carlsen (2005) concluded that owner managed businesses are run by people with more entrepreneurial attitudes because the owners tend to control and monitor all stages of the decision making process. These arguments lead us to formulate the following hypothesis:

Hypothesis 2. When the hotel establishment is managed by the owners, there is a greater probability of engaging in radical innovations than in incremental innovations.

\subsection{Market strategy}

Baum and Haveman (1997) showed that differentiation is a key competitive variable in the hotel trade. A firm's strategic decision to differentiate itself from competitors will affect its productive resources, the services it offers, the organisation and management of its operations, and, therefore, its innovation decisions (Sundbo, 1997). Therefore, innovative activity would be a consequence of the market strategy. Considering that travellers decide to book a tourist accommodation facility based on its price, on the number of services offered, on the quality of those services, and on the image of the hotel establishment (Baum and Haveman, 1997), it can be deduced that an establishment will differentiate its service offerings from those of its closest competitors by adjusting the service package to meet the demand (adjusting service) or by improving the efficiency of its provision process (improving productive efficiency). A strategic decision to differentiate may give rise to the implementation of innovative measures. In particular, the decision to undertake radical innovation is more probable in establishments for which the differentiation strategy is based on the provision process, because it involves less client contact and greater capital intensity (Damanpour, 1996). In contrast, a service differentiation strategy, which involves a greater presence of human resources, is less likely to involve radical innovation. Analogously, opting for incremental innovation is more probable in establishments in which the differentiation strategy is based on adjusting the service provided; the firm adapts itself to the demands of the clientele with the least possible risk.

Nevertheless, another important characteristic of hotel com petition in the market is the seasonal demand faced by hotel firms (Getz and Carlsen, 2005) a typical situation for sun and sea holiday destinations. This seasonal demand, combined with a structure of high fixed costs that increase the minimum occupancy level required to reach minimum acceptable profit ability (Tisdell, 2000), make it more profitable for some establish ments to close during periods of lesser tourist demand. Establishments that choose to remain open for longer periods will play a greater role in the tourist production of the destination, will have a larger information base, and will experience lower occupancy rates for periods of lesser demand. All these factors could affect decisions to innovate and may cause a greater interest and effort in maintaining an innovative offer structure that responds effectively to the seasonal nature of tourism (e.g. offering tourist products off season and searching for ways to decrease fixed costs). Acquiring more information will create a greater understanding of the determinants of competitiveness, including innovation. This accumulation of knowledge resources will favour radical innovation (Dewar and Dutton, 1986). Finally, during periods of lower occupancy, those establishments that remain open could make the most of operating at less than maximum capacity by introducing innovations that require more trials and adjustments (Sirilli and Evangelista, 1998) which, in turn, could foster the generation of new knowledge necessary for radical innovation (Dewar and Dutton, 1986). Thus, regarding market factors and hotel behaviour in the market, we formulate the following hypotheses:

Hypothesis 3a. A market strategy based on differentiating the provision process will positively affect radical innovation to a greater extent than it affects incremental innovation.

Hypothesis 3b. A market strategy based on differentiating the service provided will positively affect incremental innovation to a greater extent than it affects radical innovation. 
Hypothesis 3c. A market strategy based on enforcing the market orientation will positively affect radical innovation to a greater extent than it affects incremental innovation.

\section{Empirical analysis}

\subsection{Data and sample}

The empirical analysis is focused on hotel establishments that operate in the Balearic Islands a leading tourist destination. Although there is a wide array of possible accommodations available on the Balearic Islands (hotels, tourist apartments, campgrounds), $70 \%$ of tourists choose hotel accommodation (Instituto de Estudios Turísticos, 2001). The relevant universe for this study was the total population of hotel establishments that operate in the Balearic Islands. There were 1586 such establish ments listed in the official 2000 census of tourism companies from the Tourism Council, and this number included lodging facilities categorised as guesthouses, boarding houses, residences, apartment hotels, and hotels. Those establishments categorised as "other" were excluded from our study because or their low presence.

Unfortunately, the public databases that provide aggregate data on $\mathrm{R} \& \mathrm{D}$ expenditures, patents, and related measures are not suitable for the quantification of innovation in the hotel trade. In implementing innovation, the hotel trade does not allocate significant resources for the generation of new knowledge; nor does it typically invest in the registration of patents (Hjalager, 2002). Thus, the information for detecting innovation in the hotel trade necessarily comes from primary information sources hotel companies and our data collection instrument, an interview survey administered by trained pollsters, was specifically developed so that the managers of the lodging establishments could answer it. Concretely, the administration process consists in interviewers filling up the questionnaire with the managers responses. This questionnaire application way allow us to ensure the managers distinguish between radical and incremental innovation since the interviewer clearly ask if the first time that an innovation is introduced or is an improvement of a previous innovation. Furthermore, the interviewer could provide examples of radical and incremental innovations facilitating the managers' responses.

We chose a representative sample from the universe after stratifying it by three characteristics that make it heterogeneous: the geographical location (three islands in the Balearic archipe lago), the category of lodging, and the number of rooms available. For brevity, we use "hotel" as the label for a sample element. A representative sample of 331 hotels was chosen, selected by a random process carried out proportionally from among the strata, allowing us to obtain results with a confidence level of $95.5 \%$ (Arkin and Colton, 1963). We used a process of substitution for hotels that were unavailable and replaced each inaccessible hotel with another in the same strata; thus, the stratification was unaltered as we achieved the desired 331 interviews.

In order to obtain the relevant information levels and types of innovation and variables with which they are related we chose the directors of the selected hotels to be our respondents. The survey was piloted at nine hotels chosen to represent the heterogeneity of the universe and the set of 331 personal interviews were conducted by trained pollsters during the summer of 2001 .

\subsection{Variables}

\subsubsection{Dependent variables}

Our interview focus was the innovation decisions of each hotel establishment over the last 3 years in those functional areas, departments, or services that are key elements in the process of providing hotel accommodation (e.g. quality management and information and communication technologies). Two variables capture the different degrees of innovation: RADICAL and INCREMENTAL. The binary variable, RADICAL, takes the value of 1 if the establishment reported that it had introduced innovations for the first time in any of the functional areas, departments, or services and a value of 0 if it did not. The binary variable INCREMENTAL takes the value of 1 if the establishment reported that it had improved any of the same functional areas, departments, or services and a value of 0 if it did not. The RADICAL variable measures changing attributes that entail learning because the introduction of first time innovations would necessitate a break from an existing practice and would involve a new technology requiring new knowledge and changes in both procedures and products. The INCREMENTAL variable, which records the attributes that are added to an existing service or procedure and therefore identifies improvements of current technology, signals a lesser break with the existing practices; it involves a progressive perfecting of the technological solution previously introduced as a radical innovation. Employing an ANOVA method, we have tested the differences between these two variables, determining that they are statistically different at $1 \%$. It is possible, therefore, that the same establishment carried out both types of innovation, as is observed in Fig. 1.

The $86 \%$ of sampled establishments that decided to innovate can be classified according to the type of innovation: $1.8 \%$ undertook radical innovation only, 35.4\% undertook incremental innovation only, and $48.9 \%$ conducted both types of innovation. The innovation decision of the establishment can also be classified into two types: the 50.8\% that introduced some radical innovation independent of an incremental innovation decision and the $84.3 \%$ that introduced some incremental innovation independent of a radical innovation decision.

\subsubsection{Independent variables}

The binary variable MANAGEMENT captures the organisational resource form used to manage the establishment. MANAGEMENT

Sample distribution of innovation degrees:

Percentage of establishments from

the total sample, for each innovation

\begin{tabular}{|c|c|c|c|}
\hline \multicolumn{4}{|c|}{ Do not innovate: $13.90 \%$} \\
\hline \multirow{4}{*}{$\begin{array}{l}\text { Innovate: } \\
86.10 \%\end{array}$} & Only radical: $1.81 \%$ & & \\
\hline & & $\begin{array}{l}1 \\
1 \\
1 \\
1\end{array}$ & Radical: $50.76 \%$ \\
\hline & Both: $48.94 \%$ & $\begin{array}{l}1 \\
1 \\
1 \\
1 \\
1 \\
1\end{array}$ & \\
\hline & $\begin{array}{l}\text { Only incremental: } \\
35.35 \%\end{array}$ & $\begin{array}{l}1 \\
1 \\
1 \\
1 \\
1 \\
1 \\
1 \\
1 \\
1 \\
1 \\
1\end{array}$ & $\begin{array}{c}\text { Incremental: } \\
84.29 \%\end{array}$ \\
\hline
\end{tabular}

Fig. 1. Sample distribution of innovation degrees: percentage of establishments from the total sample, for each innovation. 
equals 1 if the owner managed the hotel business and 0 if the management contract or a rental contract for operating the hotel business is owned by another party.

The strategic decision of differentiation for each establishment is measured by the binary variables PROCESS and SERVICE. PROCESS takes the value 1 if the establishment reported that it differentiates in its provision process (a greater control of inputs, costs, and organisation of the provision process) and 0 if it did not. SERVICE takes the value 1 if the establishment reports that it differentiates on the basis of the service provided or on its presentation (a higher level of service and quality, the prioritisa tion of image, the state of assets, and the performance of personnel involved in client contact) and 0 if it does not.

The market orientation strategy is approximated by the degree of use of assets labelled as the variable MARKET, a discrete variable that takes a value equal to the number of months per year that the particular hotel stays open.

\subsubsection{Control variables}

In order to control for other organisational and behavioural characteristics in the market, we included the effects that could be derived from five control variables.

Besides the management form of the productive unit, there is another characteristic of the organisational structure that may affect the innovative behaviour of hotels: how they operate in the market. Operating in the market by forming part of a chain or conglomerate of more diverse companies provides an establish ment with greater knowledge about procedural and managerial innovations (Darr et al., 1995) and enhances information flow and other intangibles such as brand image and business reputation (Ingram and Baum, 1997). The variable that approximates the organisational structure of the productive unit as it operates in the market is the binary NOT CHAIN. It takes the value of 1 if the hotel operated in the market independently, without forming a part of any chain or conglomerate and a value of 0 if it operated by forming a part of a chain or conglomerate.

Tour operators provide a distinct commercial resource to the hotel trade. Tour operators are popular with the end client because of the greater relative pressure they can exert by acting as conduits for host demands (Aguiló et al., 2001). As mentioned by Medina Múñoz et al. (2003), these demands can be satisfied by adequate innovation decisions. The use of tour operators for the commercialisation of hotel rooms is represented by the binary variable TOUROPS, which takes the value of 1 if the average client booked the hotel stay through a tour operator, and a value of 0 if no tour operator was utilised.

The size or capacity of the productive unit the number of hotel rooms (Baum and Haveman, 1997) is one of the most relevant productive resources. As demonstrated in a number of studies, size is a relevant variable in innovation decisions (e.g. Damanpour, 1996) because size affects the implementation and profitability of these decisions. The continuous variable SIZE takes the value of the natural logarithm of the number of rooms offered in each establishment. The natural logarithm of the number of rooms is used in order to avoid the fluctuations of the non transformed variable, which has values ranging from 8 to 1743 rooms.

The age of a hotel represents organisational resources, such as experience and reputation, which could positively impinge upon innovation decisions (Baum and Mezias, 1992). The variable AGE takes a value equal to the difference between the establishment's inaugural year and the year 2000 the same reference time as for the other variables.

The location in which each establishment operates will affect proposed decisions to innovate to such an extent that location is a key competitive variable in the lodging sector (Baum and Haveman, 1997). The establishment's location is measured with the binary variable ISLANDS, which takes the value 1 if the establishment is located on the islands of Minorca, Ibiza, or Formentera; and 0 if it is located on Majorca.

\subsection{Empirical analysis}

The factors that increase the probability for radical and incremental innovation degrees are determined through the estimation of probit models (Green, 1993). This analysis serves to indicate which of the proposals in the hypotheses are factors that increase (or reduce) the expected probability of a decision to innovate radically or incrementally. However, for a better approximation of the probability of change produced by an explanatory variable, the marginal effects are calculated, and these, in turn, allow us to determine in which of the two degrees of innovation the changes are greater.

One probit model is estimated for radical innovation and another for incremental innovation, in order to determine if the determinants of the two degrees of innovation differ. The models for each innovation degree are estimated in two cases. In the first case, the estimations do not include the interdependency hypothesis with the aim of producing a model that can explain each innovation degree with only the explanatory variables. In the second case, for each of the innovation degrees, the other innovation degree is included as an independent variable in the form of instrumental variables. Including the incremental (or radical) innovation in the explanation of the radical (or incre mental) innovation allows us to detect any interdependency that might exist between the two types of innovation. Given that nearly half of the sample's elements (48.9\%; see Fig. 1 ), have decided to innovate both radically and incrementally, the inclu sion of the original dependent variables as an independent variable in the estimation of the other dependent variable could alter the richness of the adjustment of the models because the dependent variables are highly similar. In order to avoid unexpected problems derived from the similarity between the radical and incremental variables we use instrumental variables obtained by estimating the model in two steps. The first step consists in regress the INCREMENTAL and RADICAL variables on over all the explanatory variables and their interactions; then we obtain the predictions of both variables. In the second step, we introduce the new independent variables predictions of INCREMENTAL and RADICAL in the Models 3 and 4.

\section{Results}

In Table 1 we display the means and standard deviations of the variables and the correlations among them. On average, approxi mately $80 \%$ of hotels carry out incremental innovation whereas only $50 \%$ implement radical innovation. The majority of hotels use a management contract and this approach is mainly used to differentiate the service.

The estimated probit models turn out to be useful in the explanation of radical and incremental innovation degrees because, for all models, the overall effect of the explanatory variables on the dependent variable is statistically significant. For each estimated model, the coefficients that are significantly non zero indicate that the variable in question causes an increase (decrease) in the probability that the hotels innovate radically (Models 1 and 3) or incrementally (Models 2 and 4) (Table 2).

Thus, we confirm $\mathrm{H} 1 \mathrm{a}$ and $\mathrm{H} 1 \mathrm{~b}$, and conclude that interde pendency between the two types of innovation decisions exists; incremental (or radical) innovation degree increases the 
Table 1

Descriptive statistics and correlations. ${ }^{\mathrm{a}, \mathrm{b}}$

\begin{tabular}{|c|c|c|c|c|c|c|c|c|c|c|c|c|c|}
\hline Variable & Mean & s.d. & 1 & 2 & 3 & 4 & 5 & 6 & 7 & 8 & 9 & 10 & 11 \\
\hline 1. Radical & 0.5076 & 0.5007 & 1.0000 & & & & & & & & & & \\
\hline 2. Incremental & 0.8429 & 0.3644 & $0.3387^{* * *}$ & 1.0000 & & & & & & & & & \\
\hline 3. Management & 0.7190 & 0.4502 & $-0.1586^{* * *}$ & $-0.1590^{* * *}$ & 1.0000 & & & & & & & & \\
\hline 4. Process & 0.1208 & 0.3264 & $0.2169^{* * *}$ & 0.0836 & $-0.1394^{* *}$ & 1.0000 & & & & & & & \\
\hline 5. Service & 0.3837 & 0.4870 & $0.1310^{* *}$ & $0.1528^{* * *}$ & $-0.1288^{* *}$ & $0.1649^{* * *}$ & 1.0000 & & & & & & \\
\hline 6. Market & 8.2870 & 2.4120 & $0.1023^{*}$ & 0.0618 & $-0.1209^{* *}$ & $0.1098^{* *}$ & $0.1020^{*}$ & 1.0000 & & & & & \\
\hline 7. Not-chain & 0.6647 & 0.4728 & $-0.2005^{* * *}$ & $-0.2011^{* * *}$ & $0.2109^{* * *}$ & $-0.1882^{* * *}$ & $-0.1370^{* *}$ & 0.0209 & 1.0000 & & & & \\
\hline 8. Tourops & 0.8006 & 0.4002 & $0.1134^{* *}$ & $0.2209^{* * *}$ & -0.0596 & $0.1618^{* * *}$ & 0.0672 & $-0.2105^{* * *}$ & $-0.2904^{* * *}$ & 1.0000 & & & \\
\hline 9. Size & 4.8034 & 1.0892 & $0.2320^{* * *}$ & $0.2808^{* * *}$ & $-0.1400^{* *}$ & $0.2649^{* * *}$ & $0.1997^{* * *}$ & -0.0052 & $-0.5452^{* * *}$ & $0.5099^{* * *}$ & 1.0000 & & \\
\hline 10. Age & 29.4330 & 11.9120 & $-0.1303^{* *}$ & $-0.1007^{*}$ & $0.1089^{*}$ & -0.0705 & -0.0750 & -0.0758 & $0.2582^{* * *}$ & -0.0113 & $-0.1871^{* * *}$ & 1.0000 & \\
\hline 11. Islands & 0.2447 & 0.4306 & $0.2514^{* * *}$ & 0.0526 & $0.1057^{*}$ & $0.1124^{* *}$ & $0.1000^{*}$ & $-0.1875^{* * *}$ & 0.0024 & -0.0501 & -0.0042 & -0.0141 & 1.0000 \\
\hline
\end{tabular}

a Correlations calculated with 321 observations.

b *Significant at $10 \% ;{ }^{* *}$ significant at $5 \% ;{ }^{* * *}$ significant at $1 \%$.

Table 2

Results of the probit econometric estimations.

\begin{tabular}{|c|c|c|c|c|}
\hline \multirow[t]{2}{*}{ Independent variables } & \multicolumn{2}{|c|}{ Estimations without interdependency } & \multicolumn{2}{|c|}{ Estimations with instrumental interdependency } \\
\hline & $\begin{array}{l}\text { Model } 1 \\
\text { Radical }\end{array}$ & $\begin{array}{l}\text { Model } 2 \\
\text { Incremental }\end{array}$ & $\begin{array}{l}\text { Model } 3 \\
\text { Radical }\end{array}$ & $\begin{array}{l}\text { Model } 4 \\
\text { Incremental }\end{array}$ \\
\hline Management & $\begin{array}{c}-0.3798^{* *} \\
{[0.1729]}\end{array}$ & $\begin{array}{c}-0.5322^{* *} \\
{[0.2530]}\end{array}$ & $\begin{array}{c}-0.3893^{* *} \\
{[0.1752]}\end{array}$ & $\begin{array}{c}-0.5051^{* *} \\
{[0.2565]}\end{array}$ \\
\hline \multicolumn{5}{|l|}{ Strategy in } \\
\hline Process & $\begin{array}{c}0.4641^{*} \\
{[0.2576]}\end{array}$ & $\begin{array}{c}-0.1635 \\
{[0.3679]}\end{array}$ & $\begin{array}{c}0.5211^{* *} \\
{[0.2610]}\end{array}$ & $\begin{array}{c}-0.2474 \\
{[0.3779]}\end{array}$ \\
\hline Service & $\begin{array}{c}0.0582 \\
{[0.1598]}\end{array}$ & $\begin{array}{c}0.3167 \\
{[0.2087]}\end{array}$ & $\begin{array}{c}0.0289 \\
{[0.1631]}\end{array}$ & $\begin{array}{c}0.2946 \\
{[0.2106]}\end{array}$ \\
\hline Market & $\begin{array}{c}0.0755^{* *} \\
{[0.0343]}\end{array}$ & $\begin{array}{c}0.0464 \\
{[0.0426]}\end{array}$ & $\begin{array}{c}0.0706^{* *} \\
{[0.0348]}\end{array}$ & $\begin{array}{c}0.0261 \\
{[0.0442]}\end{array}$ \\
\hline Incrementalpred & & & $\begin{array}{l}1.2512^{* * *} \\
{[0.4471]}\end{array}$ & \\
\hline Radicalpred & & & & $\begin{array}{c}0.4494^{*} \\
{[0.2628]}\end{array}$ \\
\hline \multicolumn{5}{|l|}{ Controls } \\
\hline Not-chain & $\begin{array}{l}-0.141 \\
{[0.1919]}\end{array}$ & $\begin{array}{c}-0.2665 \\
{[0.2873]}\end{array}$ & $\begin{array}{c}-0.1821 \\
{[0.1931]}\end{array}$ & $\begin{array}{c}-0.1949 \\
{[0.2907]}\end{array}$ \\
\hline Tourops & $\begin{array}{c}0.18 \\
{[0.2290]}\end{array}$ & $\begin{array}{r}0.4613^{*} \\
{[0.2483]}\end{array}$ & $\begin{array}{c}-0.0312 \\
{[0.2453]}\end{array}$ & $\begin{array}{r}0.4122^{*} \\
{[0.2530]}\end{array}$ \\
\hline Size & $\begin{array}{c}0.1574^{*} \\
{[0.0937]}\end{array}$ & $\begin{array}{c}0.2747^{* *} \\
{[0.1225]}\end{array}$ & $\begin{array}{c}0.1173 \\
{[0.0968]}\end{array}$ & $\begin{array}{c}0.2426^{*} \\
{[0.1263]}\end{array}$ \\
\hline Age & $\begin{array}{c}-0.0072 \\
{[0.0064]}\end{array}$ & $\begin{array}{l}-0.003 \\
{[0.0080]}\end{array}$ & $\begin{array}{c}-0.0038 \\
{[0.0065]}\end{array}$ & $\begin{array}{c}-0.0017 \\
{[0.0083]}\end{array}$ \\
\hline Islands & $\begin{array}{l}0.9556^{* * *} \\
{[0.1912]}\end{array}$ & $\begin{array}{c}0.3231 \\
{[0.2402]}\end{array}$ & $\begin{array}{l}0.9732^{* * *} \\
{[0.1946]}\end{array}$ & $\begin{array}{c}0.0476 \\
{[0.2912]}\end{array}$ \\
\hline Constant & $\begin{array}{c}-1.2347^{* *} \\
{[0.6008]}\end{array}$ & $\begin{array}{c}-0.3934 \\
{[0.7857]}\end{array}$ & $\begin{array}{c}-2.0857^{* * *} \\
{[0.7032]}\end{array}$ & $\begin{array}{c}-0.2648 \\
{[0.8088]}\end{array}$ \\
\hline Observations & 321 & 321 & 321 & 321 \\
\hline $\operatorname{LR} \chi^{2}(7)$ & 62.94 & 44.71 & 72.53 & 47.71 \\
\hline Prob $>\chi^{2}$ & 0.0000 & 0.0000 & 0.0000 & 0.0000 \\
\hline Pseudo $R^{2}$ & 0.1414 & 0.1610 & 0.1630 & 0.1718 \\
\hline$\%$ pred. corr. & 68.22 & 84.42 & 69.47 & 85.98 \\
\hline
\end{tabular}

a The standard errors appear within square brackets.

b *Significant at $10 \%$; ${ }^{* *}$ significant at $5 \%$; ${ }^{* * *}$ significant at $1 \%$. 
probability of also implementing radical (or incremental) innova tion. In fact, the correlation between the values of the original variables, RADICAL and INCREMENTAL, is 0.34 and the $p$ value that rejects the null hypothesis of independence is smaller than 0.01 (see Table 1). Results also indicate that management by owner decreases the expected probability that a hotel establish ment innovates either radically or incrementally. Thus we cannot confirm $\mathrm{H} 2$ in the sense it is proposed.

Among the market behaviour factors, the market orientation and a strategic decision of differentiation in the provision process are factors that increase the probability of having a radical innovation style. Nevertheless, we are prevented from concluding that there are also such factors in incremental innovation. Hence, $\mathrm{H} 3 \mathrm{a}$ and $\mathrm{H} 3 \mathrm{c}$ are statistically robust.

The results relative to tour operators indicate that their use positively affects innovation of the incremental type. However, the inability to reject the null hypothesis prevents us from concluding that the presence of tour operators affects the radical innovation. We are also prevented from concluding that our variable for operating in the market by forming part of a chain or a conglomerate and our variable for age of the hotel affect the degree of innovation. The size control variable has a positive effect on both degrees of innovation, as its coefficients are present in each of the four models. In only one of three cases (Model 1 vs. Model 3) is there a loss of significance of the size coefficient in radical innovation upon adding incremental innovation as an explanatory variable. This single discrepant finding for the effects of the size variable may be due to the correlation that exists between size and both degrees of innovation. That is, the explanatory variable of incremental innovation reflects the effect of size in Model 3.

The findings for the location of the hotel on the islands of Minorca, Ibiza, or Formentera indicate that these locations are factors associated with increases in the probability of implementing radical innovation. By not rejecting the null hypotheses regarding their coefficients in Models 2 and 4, we are prevented from concluding that they are also such factors in incremental innovation.

Nevertheless, the empirical verification of the factors determi nant in both degrees of innovation (i.e. form of management and size) and the assessment of the innovation degree that these factors affect most strongly require a quantitative comparison one that is obtained by calculating the marginal effects of the four probit estimations. The marginal effects quantify the influence of the factors obtained by reporting on the change from their average values (infinitesimal change in the case of continuous variables and discrete change for binary variables) in the expected probability of the dependent variables upon changing the independent variables (Table 3).

The marginal effects indicate the influence of each innovation degree on the other: Establishments that innovate incrementally increase the expected probability of innovating radically by $41 \%$; whereas, if an establishment innovates radically, its expected probability of innovating incrementally increases by only $8.5 \%$. Regarding the management form, if management based on a contract with third parties is changed to management by the owner, the expected probability for radical innovation of that establishment decreases by $15 \%$, whereas the probability for incremental innovation decreases by $8 \%$.

The marginal effects of the variables PROCESS and ISLANDS on radical innovation are quantitatively comparable, as both vari ables are binary: the expected probability for radical innovation increases approximately $20 \%$ when a non differentiated establish ment differentiates the provision process and 35\% when an establishment is not located on the island of Majorca.

Regarding the market orientation strategy, the results indicate that by increasing the time that an establishment remains open
Table 3

Marginal effects in the estimated probit models.,

\begin{tabular}{|c|c|c|}
\hline \multirow[t]{3}{*}{ Independent variables } & \multicolumn{2}{|c|}{ Estimations with instrumental interdependency } \\
\hline & Model 3 & Model 4 \\
\hline & Radical & Incremental \\
\hline Management & $\begin{array}{c}-0.1539^{* *} \\
{[0.0679]}\end{array}$ & $\begin{array}{c}-0.0832^{* *} \\
{[0.0360]}\end{array}$ \\
\hline \multicolumn{3}{|l|}{ Strategy in } \\
\hline Process & $\begin{array}{c}0.2019^{* *} \\
{[0.0951]}\end{array}$ & $\begin{array}{l}-0.052 \\
{[0.0881]}\end{array}$ \\
\hline Service & $\begin{array}{c}0.0115 \\
{[0.0650]}\end{array}$ & $\begin{array}{c}0.0534 \\
{[0.0365]}\end{array}$ \\
\hline Market & $\begin{array}{c}0.0282^{* *} \\
{[0.0139]}\end{array}$ & $\begin{array}{c}0.0049 \\
{[0.0083]}\end{array}$ \\
\hline Incrementalpred & $\begin{array}{l}0.4111^{* * *} \\
{[0.0944]}\end{array}$ & \\
\hline Radicalpred & & $\begin{array}{c}0.0852^{*} \\
{[0.0501]}\end{array}$ \\
\hline Not-chain & $\begin{array}{c}-0.0725 \\
{[0.0766]}\end{array}$ & $\begin{array}{c}-0.0352 \\
{[0.0499]}\end{array}$ \\
\hline Tourops & $\begin{array}{c}-0.0125 \\
{[0.0979]}\end{array}$ & $\begin{array}{c}0.0896^{*} \\
{[0.0629]}\end{array}$ \\
\hline Size & $\begin{array}{c}0.0468 \\
{[0.0386]}\end{array}$ & $\begin{array}{c}0.0456^{*} \\
{[0.0238]}\end{array}$ \\
\hline Age & $\begin{array}{c}-0.0015 \\
{[0.0026]}\end{array}$ & $\begin{array}{c}-0.0003 \\
{[0.0016]}\end{array}$ \\
\hline Islands & $\begin{array}{l}0.3628^{* * *} \\
{[0.0632]}\end{array}$ & $\begin{array}{c}0.0088 \\
{[0.0531]}\end{array}$ \\
\hline
\end{tabular}

a The standard errors appear within square brackets.

b *Significant at $10 \%$; ${ }^{* *}$ significant at $5 \%$; ${ }^{* * *}$ significant at $1 \%$.

by 1 month per year, the probability for radical innovation increases by approximately $3 \%$. On the other hand, incremental innovation increases in probability by approximately $9 \%$ in cases utilising tour operators in the commercialisation of hotel rooms.

Finally, it is worth highlighting the robustness of these results. The alternative estimations of the four models lead to the same results, enabling us to conclude that, given the existing correlation between size and category (number of stars) of each establish ment, the variable SIZE takes in the influence of category on the dependent variables, yielding consistent estimators.

\section{Discussion and conclusions}

The results allow for empirical verification of the model. The hypothesis of simultaneous as opposed to sequential interdepen dency between the two degrees of innovation is supported empirically in both directions and with a different magnitude: The estimated effect of incremental innovation on radical innovation is almost five times greater than the estimated effect of radical innovation on incremental innovation. Although, by definition, incremental innovation occurs after some radical innovation, the greater effect of incremental innovation on radical innovation is not surprising, because we analysed for simulta neous interdependency. Therefore, it appears that the effect of incremental innovation is one that involves the generation, accumulation, and updating of resources and capacities for innovation (Sirilli and Evangelista, 1998). The resources and capacities developed for radical innovation would have their greatest value in the subsequent incremental innovation and a lesser value for the simultaneous innovation, whereas the 
updating of resources and capacities for incremental innovation would foster the accumulation of the essentials for innovation more generically. It seems that the disentangling of service innovation in both degrees, as Gallouj and Weinstein showed (1997), is appropriate in our analysis.

Regarding the impact of the form of management of hotels, we have found that, contrary to $\mathrm{H} 2$, non owner managers are more likely than are owner managers to undertake radical innovation. Thus, it appears that the increased risk for radical innovation that arises from the mediation of a hotel management contract is more than compensated for by the greater specialisation in manage ment and a greater understanding of the determinants of hotel competition that accompany the use of specialised (non owner) managers. Specialised management could also be positively related to a managerial attitude that is more inclined to fostering change (Damanpour, 1996; Dewar and Dutton, 1986). The non confirmed influence of operating independently vs. being part of a hotel chain or business conglomerate can be explained by noting that the knowledge, information, and other intangibles provided by the chain or conglomerate (Darr et al., 1995; Ingram and Baum, 1997) may be compensated for by the incentives derived from competition.

$\mathrm{H} 3 \mathrm{a}$ and $\mathrm{H3c}$, concerning the strategic differentiation in the provision process and in market orientation are verified empiri cally with regard to their influence on radical innovation. There fore, it can be concluded that these market factors are determinants of innovation that differ according to their degree. Compared to the service differentiation strategy, differentiation in the provision process is a determinant in radical innovation, insofar as it involves less client contact and is more capital intensive (Damanpour, 1996). The service differentiation strategy, on the other hand, involves greater presence of human resources. The failure to confirm an effect of the differentiation in the service provided could be because this style of differentiation can be achieved with small modifications that do not give rise to innovation. On the other hand, the establishments with a stronger market orientation strategy implemented over time would be able to introduce innovations that require more trials and adjustments when they are functioning below maximum capacity (Sirilli and Evangelista, 1998), thereby generating more options for radical innovation.

The finding that the use of tour operators was a determining factor for incremental innovation but not for radical innovation may be attributable to the tour operators' somewhat limited power of negotiation (Medina Múñoz et al., 2003) and to the fact that incremental innovation enables hotels to respond more rapidly and with less risk to the demand exigencies they face. The similar effect of hotel size on both degrees of innovation would indicate the higher probability of implementing both degrees of innovation because of economies of scale. Previous literature suggests a greater effect for size in radical innovation (Daman pour, 1996), but this is not verified in the Balearic hotel industry. This failure to verify a greater effect of size on radical innovation than on incremental innovation could be explained by the greater effects of size on radical innovations the generation of the basic knowledge. In the tourism industry, a large part of innovation activity is undertaken by the supply sectors from which the tourism firm obtains technologies to apply in its own innovation process (Hjalager, 2002).

The positive effect on radical innovation of being located on the islands of Minorca, Ibiza, or Formentera, rather than Majorca, may reflect the greater effort required by hotel managers on the smaller islands to remain competitive in the face of the largest island's greater capacity for operating in the market.

Previous discussion has drawn conclusions about the internal resources and market behaviours in the hotel trade that serve to increase the probability of implementing radical innovation independent of incremental innovation. However, we are aware of some limitations in our empirical analysis, mainly related with the form in which we have measured the radicalness degree. Our measure could not detect all innovations or over evaluate some others; bearing in mind this drawback, we can conclude that third party management affects radical innovation to a greater extent than it affects incremental innovation; whereas the size of the establishment appears to affect both degrees of innovation equally. The implementation of incremental innovation, a differ entiation in the provision process, a greater market orientation, and a location on the islands with less capacity to operate in the market, positively affect radical innovation. On the other hand, incremental innovation is positively influenced by radical innova tion and by recourse to tour operators.

These results provide direction for future studies by improving our understanding of innovative behaviour in the hotel sector. Our understanding would improve significantly with the utilisation of diachronic data that would permit us to analyse the delayed effects that may exist especially those that arise between the two degrees of innovation and to distinguish between structural determinants and those that arise from the conjuncture of determinants. Also, the theoretical framework used in this study could be applied to understand the radical and incremental innovation decisions in other sectors of the economy.

\section{Acknowledgements}

The authors are grateful for helpful comments received from Rafel Crespí, Isabel Gutiérrez, Xavier Molina, and Jon Sundbo. The authors acknowledge financial support for this project provided by the Regional Authority for Research, Technological Develop ment and Innovation of the Govern de les Illes Balears, Spanish Ministry of Education and Science, through the SEJ2007 67895 C04 03/ECON project and SEC2006 03963 ECO project, and by Project no. 2213 of Fundación BBVA.

\section{References}

Aguiló, P.M., Alegre, J., Riera, A., 2001. Determinants of the price of German tourist packages on the island of Mallorca. Tourism Economics 7 (1), 59-74.

Amable, B., Palombarini, S., 1998. Technichal change and incorporated R\&D in the service sector. Research Policy 27, 655-675.

Amis, J., Slack, T., 2004. The pace, sequence and linearity of radical change. Academy of Management Journal 47 (1), 15-39.

Arkin, H., Colton, R., 1963. Tables of Statisticians. Barnes and Noble, New York.

Baum, J.A.C., Haveman, H.A., 1997. Love thy neighbor? Differentiation and agglomeration in the Manahattan hotel industry. Administrative Science Quarterly 42 (2), 304-338.

Baum, J.A.C., Mezias, J.S., 1992. Localized competition and organizational failure in the Manhattan hotel industry. Administrative Science Quarterly 37, 564-580.

Balaguer, J., Cantavella-Jordá, M., 2002. Tourism as a long-run economic growth factor: the Spanish case. Applied Economics 34, 877-884.

Cardinal, L.B., 2001. Technological innovation in the pharmaceutical industry: the use of organization control in managing research and development. Organizational Science $12,19-36$.

Coombs, R., Miles, I., 2000. Innovation, measurement and services: the new problematique. In: Metcalfe, J.S., Miles, I. (Eds.), Innovation Systems in the Service Economy. Kluwer Academic Press, London, pp. 85-124.

Damanpour, F., 1991. Organizational innovation: a meta-analysis of effects of determinants and moderators. Academy of Management Journal 34 (3), 555-590.

Damanpour, F., 1996. Organizational complexity and innovation: developing and testing multiple contingency models. Management Science 42 (5), 693-716.

Danneels, E., 2002. The dynamics of product innovation and firm competences. Strategic Management Journal 23, 1095-1121.

Darr, E., Argote, L., Epple, D., 1995. The acquisition, transfer and depreciation of knowledge in service organizations: productivity in franchises. Management Science 41, 1750-1762.

Dewar, R.D., Dutton, J.E., 1986. The adoption of radical and incremental innovations: an empirical analysis. Management Science 32 (11), 1422-1433. 
Drejer, I., 2004. Identifying innovation in surveys of services: a Schumpeterian perspective. Research Policy 33 (3), 551-562.

Ettlie, J.E., Bridges, W.P., O’Keefe, R.D., 1984. Organization strategy and structural differences for radical vs. incremental innovation. Management Science 30 (6), 682-695.

Floyd, S.W., Lane, P.J., 2000. Strategizing throughout the organization: managing role conflict in strategic renewal. Academy of Management Review 25, 154-177.

Gallouj, F., Weinstein, O., 1997. Innovation in services. Research Policy 26, 537-556.

Gatignon, H., Tushman, M.L., Smith, W., Anderson, P., 2002. A structural approach to assessing innovation: construct development of innovation locus, type and characteristics. Management Science 48 (9), 1103-1122.

Getz, D., Carlsen, J., 2005. Family business in tourism. State of the art. Annals of Tourism Research 32 (1), 237-258.

Gibson, C.B., Birkinshaw, J., 2004. The antecedents, consequences, and mediating role of organizational ambidexterity. Academy of Management Journal 47, 209-226.

Green, W.H., 1993. Econometric Analysis. MacMillan, New York.

Guerrier, Y., Deery, M., 1998. Research in hospitality human resource management and organizational behaviour. Hospitality Management 17, 145-160.

He, Z., Wong, P., 2004. Exploration and exploitation: an empirical test of the ambidexterity hypothesis. Organization Science 15 (4), 481-494.

Hjalager, A.M., 1998. Environmental regulation of tourism: impact on business innovation. Progress in Tourism and Hospitality 4, 17-30.

Hjalager, A.M., 2002. Repairing innovation defectiveness in tourism. Tourism Management 23 (5), 465-474.

Huybers, T., Bennett, J., 2000. Impact of the environment on holiday destination choices of prospective UK tourists: implications for Tropical North Queensland. Tourism Economics 6 (1), 21-46.

Ingram, P., Baum, J., 1997. Chain affiliation and the failure of Manhattan hotels, 1898-1980. Administrative Science Quarterly 42, 68-102.

Instituto de Estudios Turísticos, 2001. Evolución del Turismo en España Año 2000. Ministerio de Comercio y Turismo, Madrid.

Jansen, J.J.P., Van den Bosch, F.A.J., Volberda, H.W., 2006. Exploratory innovation, exploitative innovation, and performance: effects of organizational antecedents and environmental moderators. Management Science 52 (11), 1661-1674
Landau, R., 1991. How competitiveness can be achieved: fostering economic growth and productivity. In: Landau, R. (Ed.), Technology and Economics: Papers Commemorating Ralph Landau's Service to the National Academy of Engineering. National Academy Press, Washington, DC, pp. 3-46.

Lee, J., Lee, J., Lee, H., 2003. Exploration and exploitation in the presence of network externalities. Management Science 49, 553-570.

Medina-Múñoz, R.D., Medina-Múñoz, D.R., García-Falcón, J.M., 2003. Understanding European tour operators' control on accommodation companies: an empirical evidence. Tourism Management 24 (2), 135-147.

Metcalfe, J.S., Miles, I., 2000. Introduction, overview and reprise. In: Metcalfe, J.S., Miles, I. (Eds.), Innovation Systems in the Service Economy. Kluwer Academic Press, London, pp. 1-111.

Miles, I., 2000. Services innovation: coming of age in the knowledge-based economy. International Journal of Innovation Management 4 (4), 371-389.

Ottenbacher, M., Gnoth, J., 2005. How to develop successful hospitality innovation. Cornell Hotel and Restaurant Administration Quarterly 46 (2), 205-222.

Pavitt, K., 1984. Sectoral patterns of technical change: towards a taxonomy and a theory. Research Policy 13, 343-373.

Preissl, B., 2000. Service innovation: what makes it different? Empirical evidence from Germany. In: Metcalfe, J.S., Miles, I. (Eds.), Innovations Systems in the Service Economy. Kluwer Academic Publishers, Boston.

Roberts, J., Andersen, B., Hull, R., 2000. Knowledge and innovation in the service economy. In: Anderson, B., Howells, J., Hull, R., Miles, I., Roberts, J. (Eds.), Knowledge and Innovation in the New Service Economy. Edward Elgar, Cheltenham, UK.

Rothaermel, F.T., Deeds, D.L., 2004. Exploration and exploitation alliances in Biotechnology: a system of new product development. Strategic Management Journal 25, 201-221.

Schumpeter, J.A., 1934. The Theory of Economic Development. Harvard University Press, Cambridge.

Sirilli, G., Evangelista, R., 1998. Technological innovation in services and manufacturing: results from Italian surveys. Research Policy 27 (9), 881-899.

Sundbo, J., 1997. Management of innovation in services. Service Industries Journal 17 (3), 432-455.

Tisdell, C., 2000. The Economics of Tourism. Edward Elgar Publishing Limited, Massachussets.

Tremblay, P., 1998. The economic organization of tourism. Annals of Tourism Research 25 (4), 837-859. 